\title{
Mira Moshe*
}

\section{Shaming 2.0. Social Interaction and the Construction of Shame and Shaming}

\begin{abstract}
With the rise and spread of the Web 2.0 culture the nature of "old"/"traditional" social interaction, including shame and shaming, is changing as more and more attention is given to online vs. offline social interactions. Amongst those on-going changes lies the construction of Shaming 2.0, i.e., a public attempt to impose shame on "the Other" by using Web 2.0 technological capabilities. Thus, Shaming 2.0 can be defined as a pragmatic social negotiation regarding the boundaries of what is allowed and forbidden, what is acceptable and unacceptable while performing on-line and off-line social interactions.

The illustration of Shaming 2.0 was conducted by utilizing Israeli rabbinical court decisions in the era of Web 2.0 cultural features. Via the implementation of critical discourse analysis, the rise of the "Virtual Mirror' is portrayed side by side with "new" social interactions behind the scenes of Shame 2.0.

Keywords: shame, shaming, social interaction, sharing, cyber-mob, moral panic
\end{abstract}

\section{Introduction}

In 1999 Darcy DiNucci introduced the notion of Web 2.0 (DiNucci, 1999) while predicting its power of distribution and its multiple penetrations into our lives. A few years later, Tim O'Reilly and Dale Dougherty brainstorming in the O'Reilly Media Web 2.0 Conference in late 2004 (O'Reilly, 2007) switched focus from networks depending on the hardware or the content, to networks concentrating on the participation of large-scale social communities committed to collecting and annotating data for other users (Jenkins, 2009). Namely, according to Jenkins $(2006,2009,2012)$, Web 2.0 features have become the frameworks of 'participation' and 'sharing' thus paving the way to a "convergence culture" or better yet a "participatory culture" when producing new ideas of what it means to participate in social, political and institutional life (Lewis \& Rosen, 2010). But beyond the hype of participatory online culture lays not just a new form of content production, but also a new process for the continuous creation and extension of knowledge and art by collaborative communities - the produsage (Bruns, 2008).

*Ariel University, Israel, miram@ariel.ac.il 
The produsage are members of the participatory culture, who engaged themselves with the social and symbolic construction of discursive pickets as they applicate and animate with their everyday thought, decision making, and action (Bakardjieva \& Gaden, 2012). The produsage are the ones that implement Foucault's idea regarding technologies of the self-utilization. Using Foucault's ideas and terminology, the technologies of production, sign systems, and power reshaped the technologies of the self, in a way that "permit individuals to effect by their own means or with the help of others a certain number of operations (...) so as to transform themselves in order to attain a certain state of happiness, purity, wisdom, perfection, or immortality" (Foucault, 1988, p. 18). In the Web 2.0 culture, technologies of the self are expressed through interactive systems that enable the participation of users in production and social interaction while empowering users' capacities socially and politically (Jarrett, 2008).

Web 2.0 Storytelling, for instance, improves knowledge management and enables employees to participate in knowledge creation and sharing (Meret, Iannotta \& Gatti, 2019). Moreover, knowledge sharing practices positively impact organizational performance through cost reduction, organization growth, and intangible benefits (Ali, Paris \& Gunasekaran, 2019). The applications and systems on the Web 2.0 also improve medical professionals' decisions through their knowledge sharing (Razzaque \& Hamdan, 2020), upgrade classroom communication processes via free expression of ideas (Harris \& Rea, 2019), promote and ease the cultural exchange of information hence allows students' practice in foreign language learning (Kuznetsova \& Soomro, 2019) and so on. However, side by side with the celebration of self-expressing, sharing, and participating lies guilt, shame, and shamming.

Shame is one of the foremost social mechanisms that act to preserve desirable values and acceptable behavioral norms. To a large extent, social attitudes towards shame are the result of an agreed routine of interactions between individuals and collectives. Such a routine largely depends on the activities of initial socialization agents (Monroe, 2008), in conjunction with developing awareness of social values (Bradshaw, 2005), as well as the fear of social judgment (Biddle, 1997) and its implications (Womersley, Maw \& Swartz, 2011). However, with the rise and spread of the Network Society (Castells, 2011) and the Web 2.0 culture, the emergence of Shaming 2.0 seems inevitable. Especially, since "new" communications technologies have challenged the nature of shame and shaming by generating Shaming 2.0 by converging two authentic forms - offline and online symbolic interaction. As in other Web 2.0 outcomes, preserving the authenticity of Shaming 2.0 demands an understanding of the symbolic value of shame as well as the blending, and blurring of borders among the social, physical, and virtual worlds in which Shaming 2.0 flourishes. Hence, the following research objective is to portray Shaming 2.0 via the rise of the "new" shame while utilizing Israeli rabbinical court decisions regarding the usage of communication technologies as a platform to give visibility to multiple voices.

\section{Social interaction and the construction of shame}

Western societies utilize shame as part of their attempt to maintain social order. The classical Greek period, for example, has been characterized as a "culture of shame" (Dodds, 1957), followed by the Judeo-Christian cultures, which added guilt to shame. The sanction of behavioral shame functions as a means of social control and it has a formal dimension side-by-side with an informal one. In his book, The Civilization Process (1939/1978), Nor- 
bert Elias described what he referred to as a civilization process in which shame and embarrassment became a social mechanism that deliberately allows upper-class people to distanced themselves from the ordinary people. Moreover, the bourgeoisie promotes individuals' duty to impose upon themselves internal mental punishment, e.g. feelings of shame, guilt, disgust, and remorse. Consequently, the need for formal sanctions and external social punishment was reduced. Yet, the informal dimension of the shaming sanction is of course more effective in a predominantly collective rather than in a predominantly individualistic social structure (Bechtel, 1991). Meaning, the civilization process highlighted the social and cultural role of shame (Tangney, Stuewig \& Martinez, 2014) as it activates the fear of social stigma, inadequacy, and rejection (Chapple, Ziebland \& McPherson, 2004). So, if "others" have a dramatic influence on the creation and ability to cope with a sense of shame a question may be asked - who are these "others"? Or, better yet, what is the source of their influence on the individual? In order to answer this question, we will turn to Charles Cooley and the "Looking-Glass Self" theory.

Cooley examined the link between the manner in which individuals perceive themselves and how they are perceived by others. He claimed that shame and pride are images reflected in the social mirror originating from how we perceive others' points of view. The monitoring of the self's social makeup and its developing personal-social perceptions is carried out while adhering to three principles: a) observing a social "other" that resembles us in its social characteristics; b) observing a social "other" that activates social considerations similar to ours; c) observing a social "other" that arouses an emotional response, such as shame or pride (Cooley, 1992). In simpler terms, we are ashamed because we think and feel that others are ashamed of us (Scheff, 2003).

Inspired by Cooley, Irving Goffman examined the social connection between shame and embarrassment. According to Goffman, embarrassment is a dominant emotion in the daily faceto-face interactions in which individuals are involved. When individuals feel embarrassed, they acknowledge how important social ties are for them (Scheff, 2005). However, traditionally, face-to-face interaction characterizes small groups of people, and it shapes what is generally called "minor behaviors". Minor behavior is constructed through decoding a person's or group's physiological and verbal expressions. It also considers the influence of the interaction setting, whether in a private, public, or institutional one (Goffman, 2005). Such interactions generally have a defined and clear structure or internal organization (Duncan \& Fiske, 2015) and are largely reliant on visual signs that the individual gathers from his surroundings in the course of the interaction. Thus an important step in creating face-to-face interactions is identifying intentions using eye contact, which is the central indicator of social interaction (Emery, 2000). This is not merely the ability to identify facial expressions revealing psychological or social situations; it means that eye contact enables deep psychological readings and reveals the profound aspects of social logic (Goffman, 2005), aspects that are in effect translated into creating the mirror image by self-monitoring (Shaffer, 2005).

Self-monitoring is anchored both in a sense of pride and in a sense of shame. We do not always recognize these situations since they are frequently experienced at low intensity or at what is called a "low exposure" to pride and shame (Scheff, 1988). Conversely, the threat to the social self is an important factor in experiencing shame (Gilbert, 2000). This being the case, it is possible to define shame as a negative self-image based on anticipated or actual devaluation by others as a result of not meeting up to behavioral standards (Creed, Hudson, Okhuysen \& Smith-Crowe, 2014). The source of shame is not always the result of an indi- 
vidual's gazing into the social mirror and imagining its social aspect. At times a sense of shame is caused by a shaming mechanism, a universal fixed mechanism of adherence to moral norms is enforced (Jarvis, 2016). Such a mechanism is activated by means of social-public rites managed by actors in the social community having power and representing social values (Garfinkel, 1956).

So, social power is the key to the construction of shame via the external imposition of selfimage. The individual's self-image is based on various resources, including personality, family, society, culture, profession, etc. Among the various resources from which individuals are drawing their self-image lies the prior knowledge regarding their position in the social group. Namely, via self-categorization into "in-groups" people differentiate themselves from the "others" and establish imaginary boundaries between various "in-group" and "out-group" (Tajfel, 1978). It is generally thought that belonging to a social group is rooted in striving to receive social approval and a desire to facilitate social interactions (Leary, 2007) and is likely to contribute to a person's social identity (Ellemers, Kortekaas \& Ouwerkerk, 1999). The tremendous impact of social interactions on the self inspired John Braithwaite's work on crime, shame, and reintegration, and led to the notion of re-integrative shaming (Braithwaite, 1989).

\section{Methodology}

According to Braithwaite, shaming is a mechanism of moral control based upon criticism that paves the way for reintegrating the individual by leaving room for forgiveness (Harris, 2017). Such re-integration might occur in formal, bureaucratic settings, or within an un-formal setting in the social community (Harris, 2009). In both cases, the exposer of personal information is used to protest against anti-social behavior (Rashi \& Rosenberg, 2017). Yet, a question can be posed: is the exposer of personal information in Web 2.0 used to protest against anti-social behavior?

Or, better yet, how does Shaming 2.0 re-shape the notion of shame? In order to construct and analyze Shaming 2.0, the following research was conducted.

Research field - According to Israeli law ${ }^{1}$, the marriages and divorces of Jewish citizens are conducted by the law of the Torah. In cases of divorce, the husband grants his wife a divorce, thus terminating the marriage. However, if he refuses to do so, the wife remains married, even if she no longer lives with her husband and shares his life (Shahak, 2003). From 2012 to 2017, 382 men were declared divorce refusers by rabbinical courts in Israel (Aaronson, 2017). ${ }^{2}$

Elected case study - Yaron and Mazal Attias - From 2016 to 2018, various rabbinical courts enabled three women who had been refused divorces to publish the latest court decrees regarding their cases enabling the publication of the husbands' names while calling their social milieu to ostracize them until they granted the divorces. One of the three women was Mazal Attias.

Data collection - Yaron Attias' refusal to divorce his wife, Mazal Attias, was wildly reviewed in the Israeli media, both the traditional media and the "new" ones, amongst them the Srugim website - the home site of the Zionist religious sector with which Yaron Attias and his wife, Mazal, were affiliated. The Srugim site (www.srugim.co.il) was established in 2010 as a news and features site directed at the religious Zionist community. In the month between May $5^{\text {th }}$ and June $5^{\text {th }}, 2018$, the Srugim site published 22 articles directly dealing with the Attias case, eliciting 340 reader responses, and an additional 239 discussions. Also, on the Face- 
book page of the Srugim site, responses appeared to articles dealing with the case. In general, social media sites dealt intensively with the matter and were divided between supporters of Yaron and supporters of Mazal. A campaign was launched in the latter's support under the hashtag \#Supporting_Mazal_Dadon 1\#Say_no_to_divorce_refusers.

Analysis - The representation of Shaming 2.0 was conducted by implementing critical discourse analysis (CDA). Inspired by Van Dijk (2001), the analysis focused primarily on social problems rather than on current paradigms and fashions, while embracing Fairclough's and Wodak's (1997) claim that discourse analysis is interpretative and explanatory, and that discourse is a form of social action. Discourse in Web 2.0 also focuses on language and language use. It is a set of methods grounded in linguistic discourse analysis for mining networked communication for patterns of structure and meaning, broadly construed (Herring, 2013). Hence, the current analysis followed the CDA tradition of seeking to analyze discourses as the building blocks of social interactions (Friedman, 2015).

\section{Results}

Critical discourse analysis of the 22 articles directly dealing with the Attias case, 340 eliciting readers' responses, and 239 web surfers discussions, in the Srugim site reveal some of Shame 2.0's social interactions features: shifting from "interaction" to "sharing" and "participation", flowing between establishment and anti-establishment public space, transforming the community into a mob, converting social morality into a moral panic and favoring "authenticity" over "objectivity".

\section{A) Shifting from "interaction" to "sharing" and "participation"}

Information technology (IT) has laid the foundation for the transition from "interaction" to "sharing" and "participation". While in offline interaction, much attention is paid to creating and cementing social ties, in online communication, more attention is paid to deriving advantages from the participants' activities that are dependent on one another. Thus, online shaming is not only interested in creating and strengthening social ties, but also, perhaps specifically, in gaining an advantage using emotional involvement in the shaming. On May $9^{\text {th }}, 2018$, the Srugim site first published the following article: "The Haifa Municipal Rabbinical Court has imposed the punishment of distancing and ostracism on the divorce refuser Yaron Attias.... In their ruling, the judges wrote that his name and photograph are to be disseminated to any party who is capable of convincing him to release his wife...The court's decision was posted on Facebook by his aguna (a wife whose husband refuses to divorce her)" (Sheiman, 2018, May 9).

The couple's castigation of each other in their struggle elicited 29 likes and nine responses on Facebook, all of which shamed the divorce refuser, Attias: "I wish they would lock the dog up... a primitive man like him who belongs in previous centuries in an Islamic country should be put in prison until he breaks (For the full text, see https://www.facebook.com/srugim.co.il/?fref=ts)." In opposition to the responses on the Srugim social media site, the posts on the home page tend to attack the rabbinical court judges for calling for the public humiliation of the husband, while supporting the wife's humiliation: "I declare my support of Yaron Attias! This is a man who has been forced to lose his very ex- 
istence and his life's work as a result of false accusations on the part of his spoiled wife; I salute you - don't grant the divorce" (Sheiman, 2018, May 9). As in responses to other cases, ${ }^{3}$ social sharing is likely to lead to social/civil/public participation on a much wider scale than sharing through face-to-face interaction, while also redefining the fluid, changing face of shaming.

\section{B) Flowing between establishment and anti-establishment public spheres}

The transition from "interaction" to "participation" and "sharing" is not automatic; its potential has increased as a result of advanced technological developments. The mobility of the new media, such as smartphones, for example, and the range of technological applications it offers, has generated new types of "shared participation". Such shared participation makes it possible to upload various data and transmit messages that are often perceived to be naturalistic, thus strengthening virtual shaming and including virtual punishment ${ }^{4}$. In the final analysis, the surfing community becomes the decisive factor between different narratives presented on the Web that represent non-establishment and establishment principles of justice, thus exerting pressure on the various participants in the events under discussion.

The case of the divorce refuser Yaron Attias and his wife Mazal Dadon Attias clearly illustrates the tendency to prefer non-establishment "online social justice" over the "offline social justice" meted out by the establishment. After the rabbinical court published Attias's name and image and presented him as a divorce refuser that must be ostracized, he presented his version: "In terrible, discriminatory collaboration with the welfare and legal systems, [my wife] filed complaints against me (23 complaints that were all refuted, apart from one that soon will be dismissed), distanced me from the community where I lived and from the privilege of raising our children, educating them and being part of their world. ... My life is worth nothing without my children at its center" (Ezra, 2018, May 10). This post elicited 66 responses and 40 discussions: "Yaron, I am an ultra-Orthodox man and I'm telling you that in many rabbinical courts the judges are worthless, there is anarchy, they are scared of the media, they do not consider domestic harmony, they are keen to break up families" (Ezra, 2018, May 10).

The search for non-establishment justice led one of the responders to a post published on Srugim News (2018, May 27) to claim that "... the public is not convinced that the court is right. They cannot demand of the public to act contrary to its understanding. The court has not provided explanations, so the public will not blindly follow its dictates."

The construction of counter-authority acting against the authority is liable to be recognized by representatives of authority who find it difficult to cope with the mass movement towards counter-authority and the imbalance engendered by it. Thus, in certain situations, the "new" shaming receives counter-authoritative sovereignty that does not rely on the establishment, is independent, free, and existent in its own right.

\section{C) Transforming the community into a mob}

Since the internet has become a reflection of the collective unconscious (Thom, 2017), alongside the myriad advantages of the new social media, it is difficult to ignore the fact that they have given rise to the "cyber-mob". Gustave Le Bon, one of the developers of social psychology, described in his book Mob Psychology the tendency of individuals to join the mob 
and allow themselves to be swept away into unnecessary violence, relinquish self-regulation, be overcome by fear or witness brutal, extreme behavior (Le Bon, 1921). Indeed, the cybermob is made up of two or more persons acting in cyberspace to find the party responsible for behavior whether real or imaginary that is not socially acceptable and acting together to humiliate that party while calling upon others to join in and disseminate their actions on the Net. This phenomenon has taken on proportions that make it a major part of our lives. From the moment that our collective anger button is pressed, a destructive social hurricane is released. In the case of the divorce refuser Yaron Attias, the anger button was pressed immediately with the publication of the first article written by Sheiman on May 9th, 2018: "How can that villain have a social life? Who are the disgusting people who associate with him?... Throw him to the wolves"; "He is an evil man who makes excuses in order to imprison a woman... ." Eight days later, on May $17^{\text {th }}$, one of the readers writes: "A revolting man, who is apparently also stupid. Let us pray that he ends up in prison. And that they also sue him for leaking information about closed-court proceedings." Another day passes and on May $18^{\text {th }}$, in response to another article posted on the website, one reader states: "The only way is to put a bullet in his head and leave her a widow." But there are also other voices: "Yaron Attias may be compared to Joseph the righteous who was put in prison."; "I pledge support to Yaron Attias."; "I salute you - don't grant the divorce!" etc. Although traditionally, the "cyber mob's" attacks are generally directed at women and minorities, identifying a person as inferior to us is enough to allow this to occur (Citron, 2010). It is thought that this involves "others" behaving violently and brutally, but any one of us is liable to become a bully on the Net and join the mob under cyber cover (Ronson, 2016).

Additional targets for collective rage are legal authorities, government representatives, and authority, and elites in general. In 2009 there were already signs of cyber-mobbing against politicians and elites: dissatisfaction with their decisions and an attempt to turn social media into the new arena of mob politics (Biju, 2016). In response to an article published regarding Yaron Attias on the Srugim site on May 10th, 2018, one can observe the beginnings of an attack against Israel's rabbinical courts: "It is unclear how in 2018 we are stuck with religious courts that are anything but God-fearing. So, Yaron and other injured parties, please make contact... There is already an organization collecting all the serious infractions committed by these courts under the state's protection" (Ezra, 2018, May 10).

To a large extent, these responses attest to the hybrid nature of shaming. On the one hand, the legal authorities, in this case, the rabbinical court, decided to take the very unusual step of enabling the public shaming of a divorce refuser due to its own inability to enforce its ruling against him. On the other hand, the court itself becomes an object of shaming due to its ruling. The duality of directing shaming against a person breaking the law in the real world, in offline reality, alongside directing it against those representing the law in cyberspace, in online reality, exemplifies to a large extent the hybrid nature of shaming that blends offline and online to the point of blurring the vision of one looking into the social mirror regarding who is the offender and who the victim.

\section{D) Converting social morality into a moral panic}

As previously mentioned, people are ashamed of themselves towards those whom they respect and in whose mirror image they are reflected. Namely, moral criticism has "actual weight" and the power to humiliate us increases when it is in the hands of those who are partners in a 
specific social moral reality (Calhoun, 2004). Therefore, an action or behavior that is not in line with communal moral codes will arouse a sense of shame (Gray \& Wegner, 2009) even if it does not link to a crime committed (Bedford \& Hwang, 2003). Nevertheless, the new media have blurred the boundaries between shame and guilt, or more specifically, the boundaries between shaming and accusing. Regarding the case study under discussion in the present paper, these boundaries were drawn by the legal authorities of Israel and disseminated by the various media. This being the case, examining the development of the scandal surrounding Yaron Attias clearly illustrates how such a combination can lead to moral panic (MP). ${ }^{5}$

On May $9^{\text {th }}, 2018$, it was published, for the first time, that "the Haifa Municipal Rabbinical Court has imposed the punishment of distancing and ostracism on the divorce refuser Yaron Attias of Ashdod" (Sheiman, 2018, May 9). This publication was the opening salvo that initiated the scandal that triggered moral panic as illustrated by the following headlines: "You are contemptible: A stormy interview with the divorce refuser, Yaron Attias"; "Slander: Yaron Attias demands the resignation of the radio commentator"; "The aguna replies to her refuser husband Yaron Attias. Tune in"; "The wife of the divorce refuser reveals herself and tells all. Watch the program"; "The pressure continues: The divorce refuser Yaron Attias is locked up", etc. ${ }^{6}$

When examining the phenomenon of moral panic, one learns that responses to unconventional behavior do not grow slowly as part of rationalistic coping with a truthful estimation of what has taken place, but are rather a violent, crude reaction of a "screaming mob" (Goode $\&$ Ben-Yehuda, 2010). Societies are occasionally exposed to periods of moral panic, in which people or groups are defined as a threat to social values and interests, and are portrayed stereotypically in the mass media that erect "moral barricades" (Cohen, 2002). But when outlining moral boundaries, the arousal of moral panic is often the deliberate result of a journalistic practice whose purpose is to recruit and hold public interest (McRobbie \& Thornton, 1995). Thus continual and recurring rituals of moral panic are created. Furthermore, the infiltration of the new media into social and cultural life has brought moral panic to a new level. No longer does an established and accepted moral agent bring about the event that is responded to by the participant; rather, multitudes of web surfers in general and social media buffs, in particular, assume the role of moral agents who are authorized to bring about moral panic and shaming, and countless participants either adopt or reject the significance of the moral panic and the shaming.

\section{E) Favoring "authenticity" over "objectivity"}

By their very nature, the new media generate computer-mediated communication that enables three dimensions of "being there": "presence," "co-presence" and "connected presence" (Schroeder, 2006). Presence relates to being in an environment created by a computer, rather than in a specific physical location (Witmer \& Singer, 1998). To a large extent, the "sense of being" in a particular virtual world amplifies the events occurring in it and displays them as more important than those taking place in the real world (Slater, 1999). The result is that content generated by members is preferred over that generated by the moral establishment, rendering social presence more convincing than expert opinion (Ardelet \& Brial, 2011). When examining the relative weight of experts writing on the Srugim site regarding Attias and responses to these articles, it appears that only one article responded to an opinion of a rabbi (Rabbi Amnon Bezeq of the Har Zion Yeshiva) by referring to a post published by the rabbi 
on his Facebook page, in which he wrote: "The divorce refuser Yaron Attias has been repeatedly interviewed on the media, claiming "I am not a divorce refuser; I am prepared to grant a divorce but on my terms." This claim is only a deception. There is no way to decide in an argument between two people if not by means of the rabbinical court, and the moment the court makes its decision, both sides must accept its ruling. It is of course possible to appeal acceptably, but no society can exist if anyone not liking a ruling refuses to honor it" (Ezra, 2018, May 17a).

About seventy percent of responders to the rabbi's statement as presented in the article attacked his position and directed shaming at the rabbi himself: "The rabbinical court is only interested in its media presence and not on the law of the Torah... Why don't you shame all divorce refusers... Why does the public have to obey the rabbinical court, when it doesn't really accept its authority?" (Ezra, 2018, May 17b). It appears that the "objectivity" of the establishment does not achieve its goals. Quite the opposite. An alternative, hybrid shaming flourishes. Shame 2.0 thus depends more on the content provided by "objective" surfers, who focus on undermining the establishment representatives' decisions via virtual shaming. Meaning, the shaming interaction starts as "top to bottom" one, through disseminating knowledgeable, trained professional experts' opinions. However, Web 2.0 discourse converts official authority to a "bottom-up" interaction. One that relies on an "authentic" popular experience. In other words, the "new" Shaming 2.0 seeks the "authentic" voice rather than the "objective" systematic knowledge.

\section{Discussion}

For more than a decade now, the participatory potential of social media has become synonymous with Web 2.0 platforms like Facebook and Twitter that facilitate the sharing of usergenerated content (Ankerson, 2015). One of the features developed based on sharing user-generated content, i.e. the transition from Web 1.0, "read-only", to Web 2.0, "read/write", is public shaming. A feature that seems to feed itself as in the Web 2.0 culture era.

Shaming 2.0 campaigns have the potential to spread virally as the more "likes" a shaming campaign garners, the larger an audience it reaches (Rosenblatt, 2013). Shaming $2.0-$ the public attempt to impose shame on "the Other" by using Web 2.0 platforms like Facebook and Twitter - became possible mainly due to people's tendency to "share emotions with others to manage their emotional experiences" (Bazarova, Choi, Schwanda, Cosley, \& Whitlock, 2015, p. 154). Yet, it is not only a matter of technology. When Norbert Elias attempted to explain how Europeans came to think of themselves as more "civilized" than their neighboring societies, he observed changing conceptions of shame and embarrassment. The growing awareness of shame and embarrassment played a key role in this process of internalization (Linklater \& Mennell, 2010). Inspired by Norbert Elias work on The civilizing process, Shaming 2.0 may be a manifestation or platform for reinforcing the Western civilization ethos. However, while Norbert Elias emphasized the importance of the upper-class people as a dominant game player in the civilizing process, Shame 2.0 challenges the elite role and status. It calls for the empowerment of the anti-establishment public space at the expense of the established public sphere. By shifting from "social interaction" to "emotional sharing", the transition from community to mob, from social morality to moral panic, from objectivity to authenticity is performed. 
Since "emotional sharing" is in the heart of Shame 2.0 it is important to note that people are prone to talk about the negative events they face (Zech, Rimé, \& Nils, 2004). That been said, they also derive associated benefits from sharing positive emotions. At their heart, people's most memorable experiences with Facebook are all about positive emotions, in particular those concerned with connectedness and entertainment (Sas, Dix, Hart, \& Su, 2009). Furthermore, positive emotions are situated within the emerging field of positive psychology. The broaden-and-build theory posits that experiences of positive emotions broaden people's momentary thought-action repertoires, which in turn serves to build their enduring personal resources, ranging from physical and intellectual resources to social and psychological resources (Fredrickson, 2001). However, if positive emotions build enduring personal resources, then why does Shaming 2.0 co-occur with so many negative expressions?

Well, the self becomes context-sensitive in service of the need to belong. In the above analysis, the need to belong is demonstrated through various shifts that go hands in hands with the notion of post-truth, in which emotions, beliefs, and opinions are more dominant than facts. In times of a decline in trust, a counter-public sphere emerges and alternative social forms are reviling. Moreover, its magnificent individuals' tendency to derive their worth and meaning excessively from its social context puts itself in a significantly disadvantageous position (Suh, 2007). As if the boundaries between "out there" and "in here" have been blurred. Since human emotions tend to be present simultaneously at two levels - the "out there" in our relation to our goals, the environment, and other people, and the "in here" in response to the inner life of the self (Wiley, 2003) - we are witnessing a "new" phase in the "Looking-Glass Self" theory. Namely, the online social interaction leads to negotiation regarding cultural hegemony that is responsible for marking cultural boundaries that traditionally demark offline shame, while searching for alternatives to such cultural and political hegemonies utilizing outlining and creating online shaming. The result of the "out there" and/or "in here", offline and/or online cultural clash constructs a new cultural product - Shaming 2.0.

Furthermore, the power of the conflict between our self-esteem and that perceived by us in others, together with our sense of social power and sense of security, forms the basis of our ability to suffer shame and criticism on the part of "the others" and defend ourselves in face of those who would define us differently (Gilbert, 2003). Inspired by Sartre, this means that a sense of shame marks our changing from subject to object, to a thinking person with consciousness who knows and perceives reality. This being the case, examining Shame 2.0 is also anchored, almost without exception, in the tension created by the relations between the individual and society, and the power of society to act on its members and activate them without limit. After all, "the other's" glance in our 'Virtual Mirror' calls for re-monitoring of the self's social makeup.

In the above case, while Yaron Attias looks into his social mirror via Facebook (post on June $4^{\text {th }}, 2018$ ) he portrays an authentic self, based on sharing and participation to the point of blurring between "me" and "us":

"I find it hard to describe the recent period in my life. I have been through hard psychologically challenging times, but we have arrived at a result that is to the benefit of all. Thank God, I bestowed the divorce gladly the moment $\mathbf{I}$ received the privilege to again be an active father involved in $\mathbf{m y}$ children's lives. They are the most important and for them, I would do anything. From this time forward, no matter what happens, for the sake of our children... we are setting out on a new path after separation and divorce, together with a significant return to the lives of the children and a new beginning of our own lives" (Ezra, 2018, June 4). 
In the virtual mirror of the man who was sentenced to social shaming both in the real and the cyber world, he and "the others" are one. In his mirror, the rabbinical court is the harmful destroyer, while the community is the repairer of the damage:

"I would like to thank all the dear men and women who came forward with lengthy, heartfelt prayers of unbelievable forgiveness and grace. A genuine thank you to all those righteous men and women, alive and dead, family, acquaintances, and strangers, mothers, and fathers, either whole or wounded, who supported, encouraged, strengthened, advised, and accompanied me through helplessness and insecurity, and were simply there for us..." (Ezra, 2018, June 4).

To conclude, alongside the "old" shaming, the Web 2.0 culture has brought about a profound change in shaming rituals - from social rehabilitation to social fragmentation, from integration to alienation, from blending and connecting to social separation. Clearly, the metamorphosis of shaming rituals into rejection rituals has not developed on virgin soil. It involves the transition from disciplinary societies in the spirit of Foucault, to self-disciplined societies, in which control of information leads to control over group members (Foucault, 1977). While in the $18^{\text {th }}, 19^{\text {th }}$ and $20^{\text {th }}$ centuries, a person moved from one closed environment to another, each with its own rules (family, church, school, factory, etc.) (Deleuze, 1992), today he or she moves through diffused environments that create their own rules providing regulation, direction, coordination, supervision, control, and training in a bottom-up and sideways spontaneous and voluntary manner alongside top-down corporative regulation on the part of the media organizations active in these spheres.

Thus, it can be concluded that shaming no longer relies solely upon offline social interaction, rather it also leans over online "sharing" and "participation"; it no longer takes place in established, orderly public spaces, but rather in anti-establishment spaces that reject official guardians of the peace; it is no longer conducted by and for members of the community, but by a multitude that often behaves like a mob; no longer is social morality the source of the shaming, but rather fear and incitement as a source of panic and incitement; no longer is the "objective" and the positive sought after, but rather the "subjective" and the authentic. Simply put, Shaming 2.0, which is chiefly reliant on activism, has become a threat due to the rapidity and ease of dissemination, as the social mirror no longer hangs on a domestic wall, but in a virtual city square that imposes rebuke, but also might be smashed to pieces by those looking into it, who then hang up an alternative mirror in an attempt to reflect a more attractive image of themselves.

\section{Notes}

${ }^{1}$ The Law of Rabbinical Court Judgments (Marriage and Divorce), 1953, states that matters of marriage and divorce involving Jewish citizens or residents of Israel will be under the sole jurisdiction of rabbinical courts.

${ }^{2}$ At that period, 427 women were declared divorce refusers.

${ }^{3}$ For example, an incident from August $25^{\text {th }}, 2015$, when Olivia Melville, a 23-year-old Australian woman, became the target of online harassment after a stranger posted her profile on the dating site, Tinder, on his Facebook page (Jane, 2017).

${ }^{4}$ One example of this was the "angry grandma" video clip that drew considerable attention on YouTube and discussion forums on the Net between 2006 and 2013. The film attracted unusually negative attention and resulted in universal offensive shaming on the Net. This held true even after a police report regarding the filmed incident verified that it only portrayed one possible interpretation of the incident. Web surfers were generally less interested in the police report of the incident than in the widespread shaming enabled by 
a clip photographed by a smartphone that turned a random passenger in a taxi to a victim due to a disagreement between herself and the driver (Mallén, 2016).

${ }^{5}$ A review of the literature on MPs from sociology, media studies and related fields shows a wide variety of usage and lack of conceptual clarity of the term 'moral panic'. Yet, the hybrid model of MP synthesizes theory and practice of MPs research has integrated processes and attributes while offering practical suggestions for researching and analyzing the conditions, processes and effects of MPs (Klocke \& Muschert, 2010).

${ }^{6}$ See: Ezra (2018, May 16); Ezra (2018, May 17); Srugim News (2018, May 21); Srugim News (2018, May 27); Sheiman (2018, May 30).

\section{References}

Aharonson, U. (2017). Data on rabbinical courts for the years 2012-2016 regarding divorce refusal. Freedom of Information. Retrieved from https://foi.gov.il/.

Ali, A. A., Paris, L., \& Gunasekaran, A. (2019). Key factors influencing knowledge sharing practices and its relationship with organizational performance within the oil and gas industry. Journal of Knowledge Management.

Ankerson, M. S. (2015). Social media and the "read-only" web: Reconfiguring social logics and historical boundaries. Social Media + Society, 1(2), 1-12.

Ardelet, C., \& Brial, B. (2011). Influence of the recommendations of internet users: the role of social presence and expertise. Recherche et Applications en Marketing (English Edition), 26(3), 45-67.

Bakardjieva, M., \& Gaden, G. (2012). Web 2.0 technologies of the self. Philosophy \& Technology, 25(3), 399-413.

Bazarova, N. N., Choi, Y. H., Schwanda Sosik, V., Cosley, D., \& Whitlock, J. (2015, February). Social sharing of emotions on Facebook: Channel differences, satisfaction, and replies. In Proceedings of the 18th ACM conference on computer supported cooperative work \& social computing (pp. 154-164).

Bechtel, L. M. (1991). Shame as a sanction of social control in biblical Israel: Judicial, political, and social shaming. Journal for the Study of the Old Testament, 16(49), 47-76.

Bedford, O., \& Hwang, K. K. (2003). Guilt and shame in Chinese culture: A cross-cultural framework from the perspective of morality and identity. Journal for the Theory of Social Behaviour, 33(2), 127-144.

Berry, M. (2016). Out in the open: locating new vernacular practices with smartphone cameras. Studies in Australasian Cinema, 10(1), 53-64.

Biddle, J. (1997). Shame. Australian Feminist Studies, 12(26), 227-239.

Biju, P. R. (2016). Political internet: State and politics in the age of social media. Taylor \& Francis.

Bradshaw, J. (2005). Healing the shame that binds you: Recovery classics edition. Health Communications, Inc.

Braithwaite, J. (1989). Crime, shame and reintegration. Cambridge University Press.

Bridges, T., \& Pascoe, C. J. (2014). Hybrid masculinities: New directions in the sociology of men and masculinities. Sociology Compass, 8(3), 246-258.

Bruns, A. (2008). Blogs, Wikipedia, Second Life, and beyond: From production to produsage (Vol. 45). Peter Lang.

Calhoun, C. (2004). An apology for moral shame. Journal of Political Philosophy, 12(2), 127-146.

Castells, M. (2011). The rise of the network society (Vol. 12). John Wiley \& Sons.

Chapple, A., Ziebland, S., \& McPherson, A. (2004). Stigma, shame, and blame experienced by patients with lung cancer: qualitative study. Bmj, 328(7454), 1470.

Citron, D. K. (2010). Civil rights in our information age. The offensive internet: privacy, speech, and reputation. London: Harvard University Press, pp. 31-49.

Cohen, S. (2002). Folk devils and moral panics: The creation of the mods and rockers.

Cooley, C. H. (1992). Human nature and the social order. London, UK: Transaction Publishers.

Deleuze, G. (1992). Postscript on the Societies of Control. October, 59, 3-7.

DiNucci, D. (1999). Fragmented future. Print, 53(4), 32-33.

Dodds, E. R. (1957). The Greeks and the irrational. London, UK: University of California Press. 
Douglas Creed, W. E., Hudson, B. A., Okhuysen, G. A., \& Smith-Crowe, K. (2014). Swimming in a sea of shame: Incorporating emotion into explanations of institutional reproduction and change. Academy of Management Review, 39(3), 275-301.

Duncan, S., \& Fiske, D. W. (2015). Face-to-face interaction: Research, methods, and theory. Routledge. New York, NY: Routledge.

Elias, N. (1939/1978). The civilizing process: the history of manners and State formation and civilization. Blackwel.

Ellemers, N., Kortekaas, P., \& Ouwerkerk, J. W. (1999). Self-categorisation, commitment to the group and group self-esteem as related but distinct aspects of social identity. European journal of social psychology, 29(2-3), 371-389.

Emery, N. J. (2000). The eyes have it: the neuroethology, function and evolution of social gaze. Neuroscience \& Biobehavioral Reviews, 24(6), 581-604.

Ettinger, Y. (21.2.2016). The High Rabbinical Court calls the surroundings of a stubborn divorce refuser to ostracize him. Haaretz. Retrieved from https://www.haaretz.co.il/news/law/.premium-1.2857008.

Ezra, G. (2018, June 4). Yaron Attias: We have arrived at a result that is good for all. Srugim. Retrieved from https://www.smh.com.au.

Ezra, G. (2018, May 10). I am not a divorce refuser. Yaron Attias presents the other side of the coin. Srugim. Retrieved from https://www.smh.com.au.

Ezra, G. (2018, May 16). You are contemptible!” A stormy interview with Yaron Attias. Srugim. Retrieved from https://www.smh.com.au.

Ezra, G. (2018, May 17a). Rabbi Amnon Bezeq: Whosoever sends a 'like' to a refuser cooperates with him against the rabbinical court. Srugim. Retrieved from https://www.smh.com.au.

Ezra, G. (2018, May 17b). Slander: Yaron Attias demands the resignation of the radio commentator. Srugim. Retrieved from https://www.smh.com.au.

Ezra, G. (2018, May 31). Rabbi Eli Ben Dahan: I have had a conversation with Yaron Attias; The matter is close to being resolved. Srugim. https://www.smh.com.au.

Fairclough, N. L., \& Wodak, R. (1997). Critical discourse analysis. In T. A. van Dijk (Ed.), Discourse Studies. A multidisciplinary introduction. Vol. 2. Discourse as social interaction. (pp. 258-284). London: Sage.

Foucault, M. (1977). Discipline and punish: The birth of the prison. London: Penguin Books.

Foucault, M. (1988). Technologies of the self: A seminar with Michel Foucault. Univ of Massachusetts Press.

Fredrickson, B. L. (2001). The role of positive emotions in positive psychology: The broaden-and-build theory of positive emotions. American psychologist, 56(3), 218.

Friedman, M. (2015). Mother blame, fat shame, and moral panic: "Obesity" and child welfare. Fat Studies, 4(1), 14-27.

Garfinkel, H. (1956). Conditions of successful degradation ceremonies. American journal of Sociology, 61(5), 420-424.

Gilbert, P. (2000). The relationship of shame, social anxiety and depression: The role of the evaluation of social rank. Clinical Psychology \& Psychotherapy: An International Journal of Theory \& Practice, 7(3), 174-189.

Gilbert, P. (2003). Evolution, social roles, and the differences in shame and guilt. Social Research: An International Quarterly, 70(4), 1205-1230.

Goffman, E. (2005). Interaction ritual: Essays in face to face behavior. New York, NY: Routledge.

Goode, E., \& Ben-Yehuda, N. (2010). Moral panics: The social construction of deviance. Malden, MA, USA: John Wiley \& Sons.

Gray, K., \& Wegner, D. M. (2009). Moral typecasting: divergent perceptions of moral agents and moral patients. Journal of personality and social psychology, 96(3), 505-520.

Harris, A. (2009). The role of power in shaming interactions: how social control is performed in a juvenile court. Contemporary Justice Review, 12(4), 379-399.

Harris, A. L., \& Rea, A. (2019). Web 2.0 and virtual world technologies: A growing impact on IS education. Journal of Information Systems Education, 20(2), 3.

Harris, N. (2017). Shame in regulatory settings. In Peter Drahos (Ed.) Regulatory Theory: Foundations and applications. Acton Australia: ANU Press, pp. 59-75. 
Herring, S. C. (2013). Discourse in Web 2.0: Familiar, reconfigured, and emergent. Discourse, 2, 1-25.

Jane, E. A. (2017). Feminist digilante responses to a slut-shaming on Facebook. Social Media+ Society 3(2), $1-10$.

Jarrett, K. (2008). Interactivity is evil: A critical investigation of Web 2.0. First Monday, 13(3).

Jarvis, L. C. (2016). Shame and institutional stability-or-change in healthcare. International Journal of Sociology and Social Policy, 36(3/4), 173-189.

Jenkins, H. (2006). Fans, bloggers, and gamers: Exploring participatory culture. nyu Press.

Jenkins, H. (2009). Confronting the challenges of participatory culture: Media education for the 21st century. Mit Press.

Jenkins, H. (2012). Textual poachers: Television fans and participatory culture. Routledge.

Klocke, B. V., \& Muschert, G. W. (2010). A hybrid model of moral panics: synthesizing the theory and practice of moral panic research. Sociology Compass, 4(5), 295-309.

Kuznetsova, N., \& Soomro, K. A. (2019). Students' Out-of-Class Web 2.0 Practices in Foreign Language Learning. Journal of Education and Educational Development, 6(1), 78-94.

Le Bon, G. (1921). The Crowd: A study of the popular mind. New York: Macmillan.

Leary, M. R. (2007). Motivational and emotional aspects of the self. Annu. Rev. Psychol., 58, 317-344.

Lewis, S., Pea, R., \& Rosen, J. (2010). Beyond participation to co-creation of meaning: mobile social media in generative learning communities. Social Science Information, 49(3), 351-369.

Linklater, A., \& Mennell, S. (2010). Norbert Elias, the civilizing process: Sociogenetic and psychogenetic investigations - an overview and assessment. History and Theory, 49(3), 384-411.

Mallén, A. (2016). Stirring up virtual punishment: a case of citizen journalism, authenticity and shaming. Journal of Scandinavian Studies in Criminology and Crime Prevention, 17(1), 3-18.

McRobbie, A., \& Thornton, S. L. (1995). Rethinking 'moral panic' for multi-mediated social worlds. British journal of sociology 46(4), 559-574.

Meret, C., Iannotta, M., \& Gatti, M. (2019). The power of web 2.0 storytelling to overcome knowledge sharing barriers. In ICT for a Better Life and a Better World (pp. 3-17). Springer, Cham.

Monroe, A. (2008). Shame solutions: How shame impacts school-aged children and what teachers can do to help. The Educational Forum 73(1), 58-66.

Nachshoni, K. (9.5.2018). The rabbinical court ruled: Shaming against the divorce refuser, Yaron Attias. Ynet. Retrieved from https://www.ynet.co.il/home/0,7340,L-8,00.html.

O'reilly, T. (2007). What is Web 2.0: Design patterns and business models for the next generation of software. Communications \& strategies, $1,17$.

Rabad, A. (6.3.2017). In the name of the Supreme Court and the rabbinical court: Shaming against a refuser to divorce his wife. Ynet. Retrieved from https://www.ynet.co.il/home/0,7340,L-8,00.html.

Rabinowitz, A. (2016, March). Following the Gaz Affair: On the phenomenon of divorce refusal and ways to deal with it. Psakdin. Retrieved from https://www.psakdin.co.il/.

Rashi, T., \& Rosenberg, H. (2017). Shaming in Judaism: Past, Present, Future. Journal of Religion \& Society, 19(1), 1-22.

Razzaque, A., \& Hamdan, A. (2020). Social Networking with Internet of Things Aid Bahraini Medical Professionals' Decisions Through Their Knowledge Sharing. In Toward Social Internet of Things (SIoT): Enabling Technologies, Architectures and Applications (pp. 173-182). Springer, Cham.

Ronson, J. (2016). So you've been publicly shamed. Riverhead Books.

Rosenblatt, E. L. (2013). Fear and Loathing: Shame, Shaming, and Intellectual Property. DePaul L. Rev., 63, 1.

Sas, C., Dix, A., Hart, J., \& Su, R. (2009). Dramaturgical capitalization of positive emotions: The answer for Facebook success?. People and Computers XXIII Celebrating People and Technology, 120-129.

Scheff, T. J. (1988). Shame and conformity: The deference-emotion system. American sociological review, 395-406.

Scheff, T. J. (2003). Shame in self and society. Symbolic interaction, 26(2), 239-262.

Scheff, T. J. (2005). Looking-Glass self: Goffman as symbolic interactionist. Symbolic interaction, 28(2), 147-166.

Schroeder, R. (2006). Being there together and the future of connected presence. Presence: Teleoperators and Virtual Environments, 15(4), 438-454. 
Shaffer, L. S. (2005). From mirror self-recognition to the looking-glass self: Exploring the Justification Hypothesis. Journal of Clinical Psychology, 61(1), 47-65.

Shahak, Y. (2003). A background document for deliberations on the topic of divorce delays and refusals. Knesset Research and Information Center. Retrieved from http://www.knesset.gov.il/mmm/data/pdf/ m00598.pdf.

Sheiman, Z. (2018, May 30). The pressure continues: The divorce refuser Yaron Attias is locked up. Srugim. https://www.smh.com.au.

Sheiman, Z. (2018, May 9). The rabbinical court requests: Convince this man to give his wife a divorce. Srugim. https://www.smh.com.au.

Shi, S., Zhou, X., Zhao, M., \& Huang, H. (2016). Identifying Suspected Cybermob on Tieba. In Chinese Computational Linguistics and Natural Language Processing Based on Naturally Annotated Big Data (pp. 375-386). Springer, Cham.

Slater, M. (1999). Measuring presence: A response to the Witmer and Singer presence questionnaire. Presence, 8(5), 560-565.

Srugim News. (2018, May 21). Azariah: Keep the divorce refuser, Yaron Attias, away from the Knesset. Srugim. https://www.srugim.co.il/.

Srugim News. (2018, May 21). The aguna wife responds to her husband, Yaron Attias. Srugin. Retrieved from https://www.srugim.co.il/.

Srugim News. (2018, May 27). The wife of the divorce refuser reveals herself and tells all. Watch the program. Srugim. Retrieved from https://www.srugim.co.il/.

Srugim News. (2018, May 7). The wife of the divorce refuser reveals herself and tells all. Srugim. Retrieved from https://www.srugim.co.il/.

Srugim News. (2018. June 3). An end to suffering. The divorce refuser Yaron Attias has granted his wife a divorce. Srugim. Retrieved fromhttps://www.srugim.co.il/.

Suh, E. M. (2007). Downsides of an Overly Context-Sensitive Self: Implications From the Culture and Subjective Well-Being Research. Journal of Personality, 75(6), 1321-1343.

Tajfel, H. E. (1978). Differentiation between social groups: Studies in the social psychology of intergroup relations. Academic Press.

Tangney, J. P., Stuewig, J., \& Martinez, A. G. (2014). Two faces of shame: The roles of shame and guilt in predicting recidivism. Psychological science, 25(3), 799-805.

Thom, R. C. (2017). Digital Martyrs and Shadowless Assailants: The Projective Shadow's Emergence in Cyberspace. Pacifica Graduate Institute.

Unger, Y., \& Almagor, L. O. (2011). Divorce refusal in Israel - Jewish legal and legal background, the proportions of the phenomenon and ways of dealing with it. Knesset Research and Information Center. Retrieved from http://www.knesset.gov.il/mmm/data/pdf/m03037.pdf.

Van Dijk, T. A. (2001). 18 Critical discourse analysis. The handbook of discourse analysis, 352.

Waring, J. (2014). Restratification, hybridity and professional elites: questions of power, identity and relational contingency at the points of 'professional-organisational intersection'. Sociology Compass, $8(6)$, 688-704.

Wiley, N. (2003). The Self as Self-Fulfilling Prophecy. Symbolic Interaction, 26(4), 501-513.

Witmer, B. G., \& Singer, M. J. (1998). Measuring presence in virtual environments: A presence questionnaire. Presence, 7(3), 225-240.

Womersley, G., Maw, A., \& Swartz, S. (2011). The construction of shame in feminist reflexive practice and its manifestations in a research relationship. Qualitative Inquiry, 17(9), 876-886.

Zech, E., Rimé, B., \& Nils, F. (2004). Social sharing of emotion, emotional recovery, and interpersonal aspects. The regulation of emotion, 157-185.

Zilberberg, S. (1.3.2016). Shaming against a divorce refuser. Takdin. Retrieved from http://www.takdin.co.il/ Article/Article/5267745. 